\title{
SINTESIS DAN KARAKTERISASI SELULOSA BAKTERI-SITRAT- KITOSAN SEBAGAI PEMBALUT LUKA ANTIMIKROBA
}

\section{SYNTHESIS AND CHARACTERIZATION OF BACTERIAL CELLULOSE-CITRATE- CHITOSAN AS ANTIMICROBIAL WOUND DRESSING}

\author{
Farah Nurlidar, Lely Hardiningsih dan Darmawan Darwis \\ Pusat Aplikasi Teknologi Isotop dan Radiasi - BATAN, \\ Kawasan BATAN, Pasar Jumat, Jakarta Selatan, Indonesia \\ Email: farah@batan.go.id
}

Diterima: 19 Agustus 2013, Direvisi: 8 Agustus 2013, Disetujui: 2 September 2013

\begin{abstract}
ABSTRAK
Selulosa bakteri yang diproduksi oleh bakteri Acetobacter xylinum merupakan material yang sangat baik untuk digunakan sebagai pembalut luka karena kandungan airnya yang tinggi, sifat tersebut sangat baik untuk menjaga kelembapan luka sehingga mempercepat penyembuhan luka. Akan tetapi, selulosa bakteri (BC)tidak memiliki sifat anti bakteri, penelitian ini bertujuan untuk mengembangkan pembalut luka antimikroba berbasis selulosa bakteri dan kitosan. Hasil penelitian menunjukkan pembentukan selulosa bakteri-kitosan melalui reaksi menggunakan asam sitrat meningkatkan kapasitas absorbsi dan sifat antimikrobanya. Komposit tersebut memberikan nilai kapasitas absorbsi dalam air DM sebesar $21.5 \mathrm{~g} / \mathrm{g}$ dan kapasitas absorpsi dalam larutan salin $(\mathrm{NaCl} 0,9 \%)$ sebesar $8.2 \mathrm{~g} / \mathrm{g}$, sifat ini sangat penting bagi pembalut luka untuk menyerap eksudat luka pada luka yang berair. Karakterisasi laju transmisi uap air/ WVTR (Water Vapour Ttransmission Rate) juga menunjukkan nilai WVTR semua sampel yang di uji di bawah nilai WVTR kontrol tanpa pemberian sampel .Selain itu, selulosa bakteri-sitrat-kitosan (BC-AST) juga menunjukkan sifat antimikroba yang baik terhadap E. coli, S. typhi, P. aeruginosa dan S. aureus.
\end{abstract}

Kata kunci: Antimikroba, asam sitrat, kitosan, pembalut luka, selulosa bakteri

\section{ABSTRACT}

Bacterial cellulose, produced by Acetobacter xylinum, is an interesting material for using as a wound dressing since it provides moist environment to a wound resulting in a better wound healing. However, bacterial cellulose (BC) itself has no antibacterial activity to prevent wound infection. To achieve antibacterial activity, chitosan were impregnated into bacterial cellulose by crosslinking reaction using citric acid as crosslinker. The thickness, water and saline absorption capacity, water vapour transmission rate (WVTR), mechanical properties and antibacterial activity of composite were investigated. The result show an important increase in absorption capacity when $B C$ was treated with citric acid and chitosan and the maximum value was reached at $21.5 \mathrm{~g} / \mathrm{g}$ in DM water and $8.2 \mathrm{~g} / \mathrm{g}$ in saline solution). The WVTR analysis of all the test membranes was found to be less than WVTR value of control without sample. The result also showed that bacterial cellulose-citrate-chitosan (BC-AST) exhibited antibacterial activity against $E$. coli, S. typhi, $P$. aeruginosa and $S$. aureus

Keywords: Antibacterial, bacterial cellulose,citric acid, chitosan, wound dressing. 


\section{PENDAHULUAN}

Selulosa bakteri $(B C)$ merupakan material yang sangat menarik dan telah banyak diaplikasikan dalam berbagai bidang seperti, industri makanan misalnya nata de coco, industri kertas (produk kertas tahan api), dan juga dalam bidang kedokteran sebagai pembalut luka dan material pada regenerasi tulang dan jaringan ${ }^{(1-3)}$.

Di dalam bidang kedokteran, membran BC memiliki potensi yang sangat baik untuk digunakan sebagai pembalut luka, karena memiliki kandungan air yang tinggi $(98-99 \%)^{(1,2,4)}$. Beberapa penelitian menunjukkan bahwa kemampuan menyerap air pada pembalut luka sangat diperlukan untuk menjaga tingkat kelembaban luka pada tingkat tertentu sehinga proses penyembuhan dapat berjalan optimal. Selain itu, karakteristik penting lain dari pembalut luka adalah sebagai pelindung terhadap benturan fisik dan masuknya infeksi mikroorganisme dari luar ${ }^{(1,5)}$. Infeksi mikroorganisme terhadap luka dapat berakibat pada kerusakan jaringan yang lebih parah dan dapat membahayakan jiwa pasien ${ }^{(5)}$.

BC diketahui sangat baik untuk digunakan sebagai pembalut luka dan mempercepat proses penyembuhan pada luka bakar dan kronis ${ }^{(1)}$. Akan tetapi, BC tidak memiliki sifat antimikroba untuk mencegah terjadinya infeksi sekunder pada luka. Oleh karena itu, pada penelitian ini dilakukan modifikasi BC untuk meningkatkan sifat antimikrobanya.

Kitosan merupakan biopolimer turunan dari kitin dan memiliki aktifitas biologi yang baik diantaranya bersifat antimikroba. Oleh karena itu, kitosan banyak digunakan dalam berbagai bidang diantaranya, bidang kedokteran, farmasi, makanan dan pertanian ${ }^{(6,7)}$. Selain itu, beberapa penelitian menyebutkan produk degradasi kitosan oleh enzim dalam tubuh manusia dapat mempercepat proses penyembuhan luka dengan menstimulasi proses regenerasi jaringan ${ }^{(7)}$. Dalam penelitian ini, asam sitrat digunakan sebagai agen pengikat silang ${ }^{(8)}$. Selain itu, keberadaan gugus sitrat dalam selulosa bakteri juga diharapkan dapat meningkatkan sifat antimikroba dari BC, hal ini dikarenakan sitrat memiliki sifat antimikroba yang baik terhadap beberapa bakteri seperti, Escherichia coli (E. coli), Staphylococcus aureus ( $S$. aureus) dan Bacillus substilis $(\text { B. substilis })^{(9,10)}$.

Penelitian ini bertujuan meneliti kemungkinan pemakaian selulosa bakterisitrat-kitosan sebagai pembalut luka antimikroba. Pada penelitian ini akan dilakukan pengujian berupa kekuatan tarik, kapasitas absorpsi, laju transmisi uap air (LTUR) dan aktivitas antimikrobanya terhadap beberapa bakteri yaitu: $P$. aeruginosa, S. typhi, E. coli dan S.aureus.

\section{BAHAN DAN METODA}

\section{Bahan}

Air kelapa, bakteri Acetobacter xylinum, amonium sulfat (Merck), asam asetatglasial (Merck), sodium hidroksida (Merck), asam sitrat (Merck), kitosan (DD $70-75 \%$, produksi BATAN) dan sodium klorida (Merck).

\section{Peralatan}

Peralatan gelas,thickness gauge (Mitutoyo, Jepang), alat uji kekuatan tarik (Strograph R1, Toyoseiki, Jepang), oven blower (Precision, USA), oven pemanas (Fischer model 301, USA), oven inkubator (HiTEC, Yamato, Jepang) dan neraca analitik (Sartorius, model BL 210 S).

\section{Metoda}

\section{Pembuatan Selulosa Bakteri}

Selulosa bakteri dibuat dari hasil fermentasi bakteri Acetobacter xylinum dalam media air kelapa sesuai dengan modifikasi prosedur yang dilakukan oleh Darwis dkk. ${ }^{(11)}$. Satu liter air kelapa yang telah disaring dimasukkan ke dalam erlenmeyer kemudian ditambahkan 20\% (b/v) sukrosa dan $0,5 \%$ (b/v) amonium sulfat, larutan kemudian diaduk sampai 
homogen dan dilakukan penambahan asam asetat glasial (p.a) sampai pH 4. Campuran tersebut selanjutnya dipanaskan hingga mendidih, kemudian didinginkan dan ditambahkan $20 \% \quad(\mathrm{v} / \mathrm{v}) \quad$ starterA. xylinumdan di inkubasi selama 4-6 hari pada suhu $30+2^{\circ} \mathrm{C}$. Pelikel selulosa bakteri yang dihasilkan dimurnikan dengan menggunakan larutan $\mathrm{NaOH} 0,1$ M pada suhu $60-65^{\circ} \mathrm{C}$ selama 4 jam dan dicuci dengan air demineralisasi (DM) hingga $\mathrm{pH}$ netral. Pelikel yang telah murni di simpan dalam air demineralisasi pada suhu + $10^{\circ} \mathrm{C}$.

\section{Pembuatan Selulosa Bakteri -Kitosan (BC-CH)}

Pelikel selulosa bakteri direndam dalam larutan kitosan $1 \%(\mathrm{~b} / \mathrm{v})$ dalam asam asetat $0,5 \%(\mathrm{v} / \mathrm{v})$ pada suhu kamar selama 24 jam. Selanjutnya, pelikel dicuci dengan air DM sebanyak 3 x $50 \mathrm{~mL}$ untuk menghilangkan sisa kitosan dan kemudian dikeringkan dengan mengunakan oven blower pada suhu kamar hingga kadar airnya $+5 \%$.

\section{Pembuatan Selulosa Bakteri-Sitrat- Kitosan (BC-AST)}

$18 \mathrm{~g}$ pelikel selulosa bakteri direaksikan dengan $20 \mathrm{~mL}$ larutan asam sitrat $5 \%(\mathrm{~b} / \mathrm{v})$ dan $\mathrm{NaH}_{2} \mathrm{PO}_{4} \quad 1 \%$ (b/v) pada suhu $140^{\circ} \mathrm{C}$ selama 3 jam. Selanjutnya, pelikel dicuci dengan air DM sebanyak $3 \times 50 \mathrm{~mL}$ untuk menghilangkan sisa-sisa asam sitrat. Pelikel kemudian direaksikan dengan larutan kitosan 1\% $(\mathrm{b} / \mathrm{v})$ dalam asam asetat $0,5 \%(\mathrm{v} / \mathrm{v})$ pada suhu $140^{\circ} \mathrm{C}$ selama 3 jam (BC-AST3) dan 5 jam (BC-AST5), reaksi dilakukan pada $\mathrm{pH} 4$ dengan menambahkan larutan natrium asetat $1 \mathrm{M}$. Hasil reaksi dicuci dengan air DM sebanyak 3 x $50 \mathrm{~mL}$. Pelikel selulosa bakteri-sitrat-kitosan selanjutnya dikeringkan dengan mengunakan oven blower pada suhu kamar hingga kadar airnya $+5 \%$.

\section{Berat dan Ketebalan Membran}

Berat membran BC diukur secara gravimetri menggunakan neraca analitik (Sartorius, model BL 210S), sedangkan ketebalan membran BC diukur menggunakan alat thickness gauge (Mitutoyo, Jepang) dengan ketelitian 0,01 $\mathrm{mm}$. Hail pengujian merupakan nilai ratarata dari tiga kali pengukuran.

\section{Kapasitas Absorpsi}

Pengujian kapasitas absorpsi dilakukan dengan metoda gravimetri. Membran BC, BC-CH dan BC-AST direndam dalam air DM dan larutan salin ( $\mathrm{NaCl}$ 0,9\%) selama waktu tertentu kemudian diambil dan air yang menempel pada permukaan sampel dikeringkan perlahan (gently blotting) menggunakan kertas saring. Kapasitas absorpsi (g/g) dihitung dengan menggunakan persamaan (1), yaitu:

Kapasitas Absorpsi $(\mathrm{g} / \mathrm{g})=\left(\frac{W_{t}-W_{0}}{W_{0}}\right)$

Keterangan:

$\mathrm{W}_{\mathrm{t}}=$ berat sampel setelah menyerap air selama $\mathrm{t}$ jam $(\mathrm{g})$

$\mathrm{W}_{0} \quad=$ berat awal sampel $(\mathrm{g})$

\section{Kekuatan Tarik}

Kekuatan tarik BC diuji dengan alat uji kekuatan tarik tipe Strograph R1 (Toyoseiki Co.Ltd., Jepang). Membran dibentuk dumbbell sesuai ASTM D-1822$\mathrm{L}$ dan ditarik dengan kecepatan crosshead $25 \mathrm{~cm} /$ menit. Kekuatan tarik rata-rata dihitung dari lima kali pengukuran.

\section{Laju Transmisi Uap Air (LTUR)}

Laju transmisi uap air dilakukan dengan menggunakan metoda yang dideskripsikan dalam ASTM E 96-95. Pada metoda ini, wadah alumunium (diameter lubang terbuka $=36 \mathrm{~mm}$ ) diisi dengan air DM dan pada bagian lubang terbukanya ditutupi dengan membran $\mathrm{BC}$, sekeliling membran kemudian diberi lilin (wax) untuk mencegah penguapan air. Wadah alumunium tersebut kemudian 
disimpan dalam oven tertutup pada suhu $37^{\circ} \mathrm{C}$ dan kelembaban relatif $49 \%$. Penguapan air melalui membran BC diamati dengan mengukur berat air yang hilang sebagai fungsi waktu ${ }^{(5,12)}$. Nilai LTUR dihitung menggunakan gradien/kemiringan kurva antara waktu (jam) dan berat air (g) yang hilang oleh penguapan dengan menggunakan persamaan berikut:

$$
\text { LTUR }=\frac{\text { gradien } \times 24}{A} \mathrm{~g} / \mathrm{m}^{2} / \text { hari }
$$

Dimana, $\mathrm{A}=$ Luas area membran dalam $\mathrm{m}^{2}$.

\section{Uji Antimikroba}

Pengujian antimikroba membran BC dilakukan dengan metoda difusi agar menggunakan bakteri gram-positif dan gram-negatif yaitu $P$. aeruginosa, $S$. typhi, $E$. coli dan $S$. aureus. Metoda ini menggunakan 2 lapis medium agar, lapisan pertama yaitu lapisan dasar/base layer dan lapisan kedua yaitu lapisan yang mengandung bakteri/seed layer ${ }^{13}$. Base layer dibuat dengan menempatkan $12 \mathrm{~mL}$ medium agar steril ke dalam cawan petri steril, setelah base layer membeku kemudian ditambahkan $8 \mathrm{~mL}$ medium agar yang mengandung bakteri dengan konsentrasi tertentu sehingga konsentrasi akhir pada medium agar tersebut berkisar antara $\quad 10^{6} \square-10^{8} \quad \mathrm{koloni} / \mathrm{mL}$, hasil perhitungan jumlah koloni masing-masing bakteri disajikan pada Tabel 1 .

Tabel 1. Tipe dan konsentrasi bakteri yang digunakan

\begin{tabular}{llc}
\hline \multicolumn{1}{c}{ Bakteri } & $\begin{array}{c}\text { Tipe } \\
\text { Bakteri }\end{array}$ & $\begin{array}{c}\text { Konsentrasi } \\
\text { bakteri } \\
\text { (koloni/mL) }\end{array}$ \\
\hline $\begin{array}{l}\text { Salmonella } \\
\text { typhi }\end{array}$ & $\begin{array}{l}\text { Gram- } \\
\text { negative } \\
\text { bacilli }\end{array}$ & $1,7 \times 10^{7}$ \\
$\begin{array}{l}\text { Pseudomonas } \\
\text { aeruginosa }\end{array}$ & $\begin{array}{l}\text { Gram- } \\
\text { negative } \\
\text { bacilli }\end{array}$ & $2,1 \times 10^{7}$ \\
Escherichia & $\begin{array}{l}\text { Gram- } \\
\text { negative } \\
\text { coli }\end{array}$ & $4,3 \times 10^{7}$ \\
& \multicolumn{3}{c}{} \\
\hline
\end{tabular}

\begin{tabular}{lll}
\hline $\begin{array}{l}\text { Staphylococcus } \\
\text { aureus }\end{array}$ & $\begin{array}{l}\text { Gram- } \\
\text { positive } \\
\text { cocci }\end{array}$ & $1,4 \times 10^{7}$ \\
\hline
\end{tabular}

Setelah lapisan agar yang mengandung bakteri memadat, membran $\mathrm{BC}$ berdiameter $0,5 \mathrm{~cm}$ diletakkan dipermukaan lapisan seed layer kemudian diinkubasi pada suhu $37^{\circ} \mathrm{C}$ selama 24 jam. Aktivitas antimikroba membran BC ditentukan berdasarkan ada/tidaknya zona inhibisi yang terbentuk di sekeliling membran.

\section{HASIL DAN PEMBAHASAN}

\section{Kapasitas absorpsi}

Kapasitas absorpsi merupakan parameter penting yang harus dimiliki oleh pembalut luka. Sifat ini diperlukan pada luka berair, dimana sifat kapasitas absorpsi yang tinggi dapat berfungsi sebagai penyerap eksudat luka ${ }^{(1,5)}$. Hasil pengujian kapasitas absorpsi BC dalam air DM dan air salin $(\mathrm{NaCl} 0,9 \%)$ disajikan pada Tabel 2. Perbedaan kapasitas absorpsi antara $B C$ dan $\mathrm{BC}-\mathrm{CH}$ dapat dijelaskan berdasarkan fasa kristalin dan amorf dari BC. Kemampuan menyerap air dari $\mathrm{BC}$ berkaitan erat dengan fasa amorfnya. Semakin sedikit jumlah fasa amorf, maka akan semakin sedikit pula jumlah air yang terjebak secara fisik di dalam fasa amorf BC. Selain itu, pada BC-CH terjadi interaksi berupa ikatan hidrogen intermolekular antara gugus $-\mathrm{OH}$ dari $\mathrm{BC}$ dan gugus $-\mathrm{NH}_{2}$ dari kitosan, terjadinya ikatan ini membuat struktur BC menjadi lebih rigid/rapat sehingga mengurangi kapasitas absorpsinya ${ }^{(7)}$.

Kapasitas absorpsi BC mengalami peningkatan setelah direaksikan dengan asam sitrat dan kitosan. Kapasitas absorpsi maksimum diberikan oleh BC-AST3 (21,5 $\mathrm{g} / \mathrm{g}$ dalam air DM dan 8,2 g/g dalam larutan salin). Peningkatan kapasitas absorpsi tersebut disebabkan oleh penambahan gugus asam karboksilat pada $\mathrm{BC}$ dari reaksi antara $\mathrm{BC}$ dan asam sitrat yang diikuti dengan reaksi dengan kitosan 
${ }^{(8)}$.Terjadinya reaksi antara $\mathrm{BC}$, sitrat dan kitosan juga ditunjukkan oleh penambahan berat dan tebal BC-AST3 dan BC-AST5 dibandingkan $\mathrm{BC}$ dan $\mathrm{BC}-\mathrm{CH}$ seperti disajikan pada Tabel 2.

\section{Kekuatan tarik}

Hasil kekuatan tarik BC disajikan pada Tabel 2. Membran BC pada penelitian ini memberikan kekuatan tarik yang tinggi sebagai hasil dari ikatan hidrogen intramolekuler dan intermolekular ${ }^{(2)}$. Penambahan kitosan pada $\mathrm{BC}-\mathrm{CH}$ menurunkan kekuatan tarik $\mathrm{BC}$, hal ini dikarenakan berkurangnya derajat kristalinitas dari $\mathrm{BC}-\mathrm{CH}^{(7)}$. Penurunan kekuatan tarik juga diberikan oleh BC-AST3 dan BC-AST5. Indriyati dkk. menyebutkan bahwa keberadaan fasa eksternal pada $\mathrm{BC}$ cenderung menurunkan kekuatan ikatan hidrogen intermolekular sehingga menurunkan kekuatan $\operatorname{tariknya}^{(14)}$.

\section{Laju Transmisi Uap Air (LTUR)}

Laju penguapan air yang tinggi pada permukaan luka sangat berpengaruh terhadap kecepatan penyembuhan luka. Oleh karena itu, pembalut luka diperlukan untuk mencegah penguapan air secara berlebihan dari permukaan luka. Hasil penelitian memberikan data bahwa laju penguapan uap air (LTUR) untuk kulit normal adalah $204+12 \mathrm{~g} / \mathrm{m}^{2} /$ hari, sedangkan untuk kulit yang terluka berkisar antara 278,4+ 26,4 - 5138,4 + $201,6 \mathrm{~g} / \mathrm{m}^{2} /$ hari ${ }^{(5,12)}$. Berdasarkan hal tersebut, nilai LTUR pembalut luka direkomendasikan pada rentang 2000-2500 $\mathrm{g} / \mathrm{m}^{2} /$ hari, nilai ini dianggap cukup untuk menjaga kelembaban luka dan mencegah dehidrasi luka ${ }^{(5,12)}$. Besarnya penguapan air (g) sebagai fungsi waktu dari membran $\mathrm{BC}, \mathrm{BC}-\mathrm{CH}, \mathrm{BC}-\mathrm{AST} 3$ dan BC-AST5 disajikan pada Gambar 1. Gradien/kemiringan dari setiap garis menunjukkan nilai trasmisi uap air $(\mathrm{g})$ per jam, nilai gradien ini kemudian dikonversikan menjadi nilai LTUR lewat persamaan $(2)^{(5,12)}$.

Pada Gambar 1 dapat dilihat bahwa kontrol tanpa pemberian membran memberikan nilai penguapan air yang sangat tinggi dan penguapan air berkurang secara signifikan dengan penggunaan membran BC. Hasil ini mengindikasikan bahwa membran $\mathrm{BC}$ sangat berpotensi untuk digunakan sebagai pembalut luka karena dapat menjaga kelembaban dan mencegah penguapan air secara berlebihan.

Tabel 2. Pertambahan berat, tebal, kekuatan tarik, kapasitas absorpsi dalam air DM dan larutan salin $(\mathrm{NaCl}$ 0,9\%) dari membran $\mathrm{BC}, \mathrm{BC}-\mathrm{CH}, \mathrm{BC}-\mathrm{AST} 3$ dan BC-AST5.

\begin{tabular}{|c|c|c|c|c|c|c|}
\hline Sampel & $\begin{array}{c}\text { Berat } \\
(\mathrm{mg})\end{array}$ & & $\begin{array}{l}\text { Tebal } \\
(\mathrm{mm})\end{array}$ & $\begin{array}{l}\text { Absorpsi Air } \\
\text { (air DM) } \\
\text { (g/g) } \\
\text { dalam } 1 \text { jam }\end{array}$ & $\begin{array}{c}\text { Absorpsi Salin } \\
\text { (NaCl 0,9\%) } \\
\text { (g/g) } \\
\text { dalam } 1 \text { jam }\end{array}$ & $\begin{array}{c}\text { Kekuatan } \\
\text { Tarik } \\
\left(\mathbf{N} / \mathbf{m m}^{2}\right)\end{array}$ \\
\hline $\mathrm{BC}$ & $\begin{array}{r}5,9 \\
0,45\end{array}$ & + & $0,05+0,003$ & $1,6+0,1$ & $1,2+0,2$ & $147,8+25,1$ \\
\hline $\mathrm{BC}-\mathrm{CH}$ & $\begin{array}{r}8,1 \\
0,25\end{array}$ & + & $0,06+0,008$ & $1,2+0,1$ & $1,2+0,2$ & $119,0+29,3$ \\
\hline $\begin{array}{l}\text { BC- } \\
\text { AST3 }\end{array}$ & $\begin{array}{c}13,2 \\
0,51\end{array}$ & + & $0,22+0,031$ & $21,5+0,6$ & $8,2+0,5$ & $11,8+3,4$ \\
\hline $\begin{array}{l}\text { BC- } \\
\text { AST5 }\end{array}$ & $\begin{array}{c}17,9 \\
0,91\end{array}$ & + & $0,27+0,010$ & $9,0+1,3$ & $6,8+1,0$ & $9,1+0,8$ \\
\hline
\end{tabular}




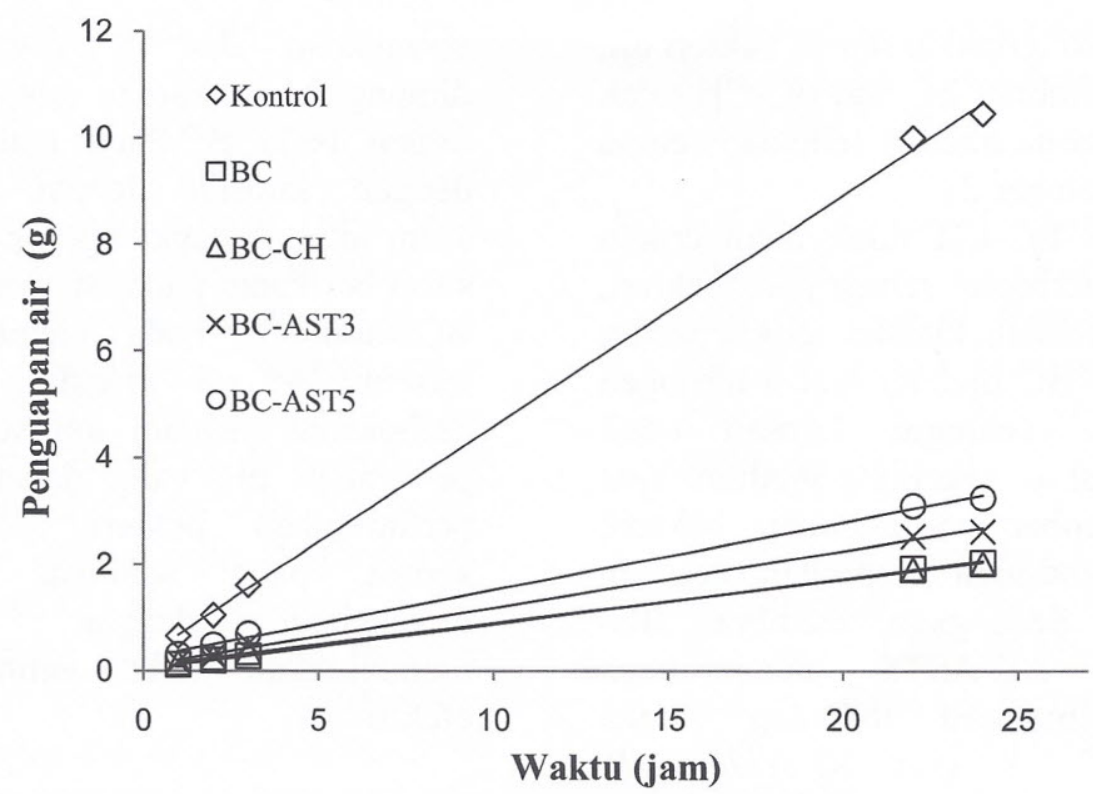

Gambar 1. Kurva penguapan air (g) sebagai fungsi waktu pada uji LTUR untuk kontrol (tanpamembran), membran $\mathrm{BC}, \mathrm{BC}-\mathrm{CH}, \mathrm{BC}-\mathrm{AST} 3$ dan $\mathrm{BC}-$ AST5.

Tabel 3. Nilai LTUR dari membran BC, BC-CH, BC-AST3 dan BC-AST5.

\begin{tabular}{lccc}
\hline \multicolumn{1}{c}{ Sampel } & Diameter Lubang $\left(\mathbf{m}^{2}\right)$ & Gradien & LTUR(g/ $\left.\mathbf{~}^{2} / \mathbf{h a r i}\right)$ \\
\hline Kontrol & $10,183 \times 10^{-4}$ & 0,433 & 10205,39 \\
BC & $10,183 \times 10^{-4}$ & 0,084 & 1979,80 \\
BC-CH & $10,183 \times 10^{-4}$ & 0,080 & 1885,52 \\
BC-AST3 & $10,183 \times 10^{-4}$ & 0,117 & 2757,58 \\
BC-AST5 & $10,183 \times 10^{-4}$ & 0,127 & 2993,27 \\
\hline
\end{tabular}

Hasil perhitungan LTUR dirangkum dalam Tabel 3, hasil perhitungan menunjukkan membran BC-AST3 dan BC-AST5 memiliki nilai LTUR yang cukup tinggi yaitu 2757,58 dan 2993,27 $\mathrm{g} / \mathrm{m}^{2} /$ hari, akan tetapi nilai LTUR tersebut mendekati rentang nilai. LTUR yang direkomendasikan untuk material pembalut luka yaitu antara 2000-2500 $\mathrm{g} / \mathrm{m}^{2} /$ hari $^{(5,12)}$. Tingginya nilai LTUR dari membran BC-AST sesuai dengan hasil pengujian kapasitas absorpsinya, keberadaan gugus karboksilat pada membran BC-AST meningkatkan nilai LTUR karena terjadinya interaksi antara air dengan gugus karboksilat pada BC-
AST melalui ikatan hidrogen.

\section{Aktivitas Antimikroba}

Infeksi sekunder pada luka merupakan salah satu masalah serius dalam penanganan dan perawatan luka. Beberapa penelitian melaporkan bahwa kitosan memiliki sifat antimikroba yang cukup baik, pada penelitian ini penambahan kitosan diharapkan dapat memperbaiki sifat antimikroba pada BC. Aktifitas antimikroba membran $\mathrm{BC}, \mathrm{BC}-\mathrm{CH}$ dan BC-AST di uji dengan menggunakan metoda difusi agar.Hasil pengujian menunjukkan membran BC-AST3 dan BC-AST5 memberikan zona 
hambat/inhibisi terhadap semua bakteri uji, sedangkan membran $\mathrm{BC}$ dan $\mathrm{BC}-\mathrm{CH}$ tidak memberikan zona hambat terhadap semua bakteri uji (Gambar 2).

Membran BC-CH tidak memberikan zona hambat terhadap semua jenis bakteri, hal ini dikarenakan kitosan terikat secara kuat terhadap BC melalui ikatan hidrogen intermolekular sehingga kitosan tidak dapat berdifusi ke sekeliling medium agar dan menghambat pertumbuhan bakteri, hasil yang sama juga dilaporkan oleh Lin dkk. ${ }^{(7)}$. Sedangkan, membran BCAST3 dan BC-AST5 menunjukkan aktifitas antimikroba terhadap semua bakteri yaitu E. coli, S. typhi, P.
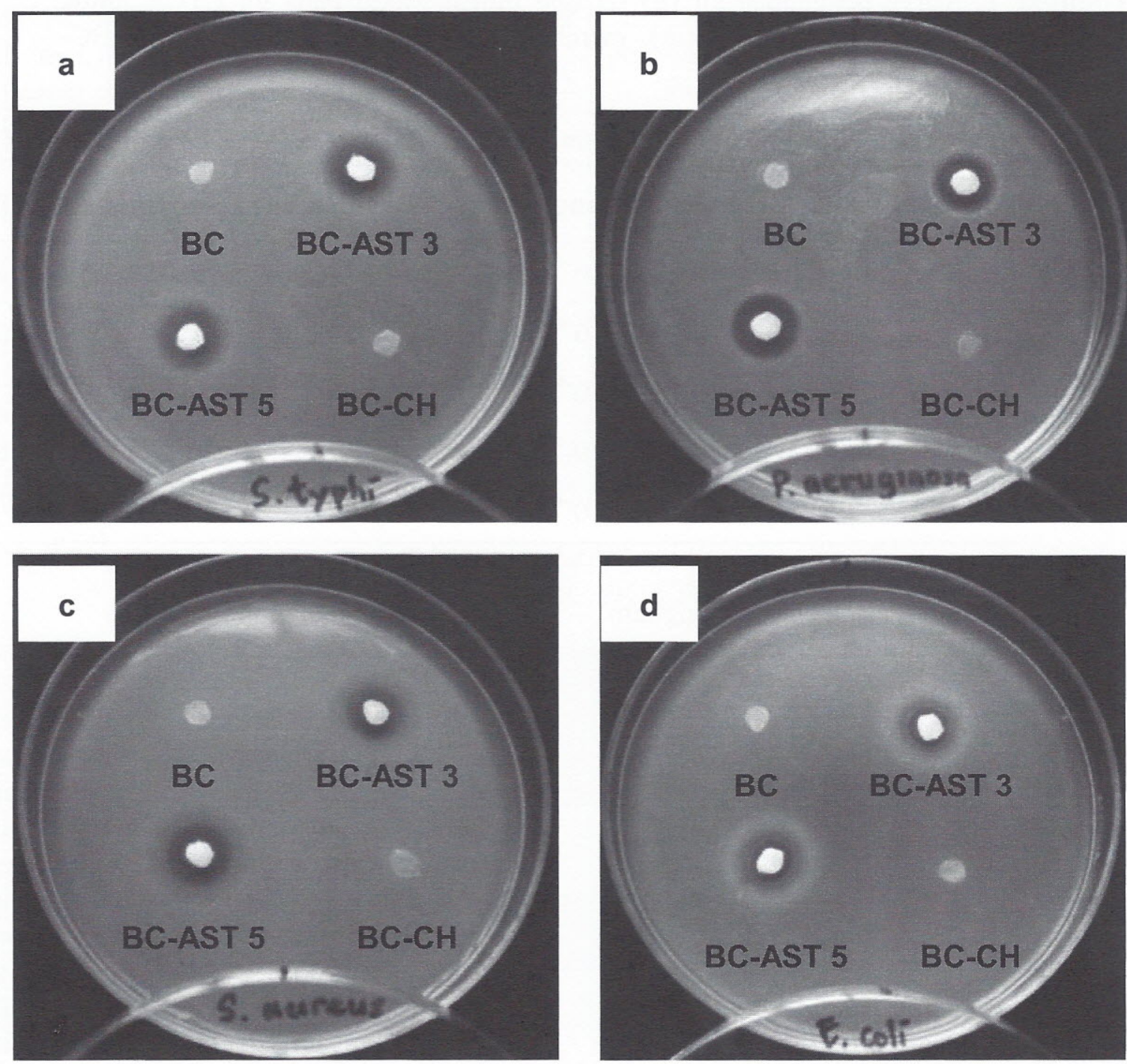

Gambar 2. Perbandingan aktivitas antimikroba dari BC, BC-CH, BC-AST3 dan BC-AST5 terhadap (a) S. Typhi, (b) P. Aeruginosa, (c) S. Aureus, (d) E. Coli. 


\section{KESIMPULAN}

Dari hasil penelitian ini dapat disimpulkan bahwa modifikasi selulosa bakteri menggunakan asam sitrat dan kitosan meningkatkan kapasitas absorpsi dan sifat antibakteri membran BC.Membran selulosa bakteri-sitratkitosan (BC-AST) memberikan nilai kapasitas absorbsi dalam air demineralisasi (DM) sebesar 21,5 g/g dan kapasitas absorpsi dalam larutan salin $(\mathrm{NaCl} 0,9 \%)$ 8,2 g/g.BC-AST menunjukkan sifat antimikroba yang baik terhadap bakteri Pseudomonas aeruginosa, Salmonella typhi, Escherichia coli dan Staphylococcus aureus. Nilai pengujian laju transmisi uap air/LTUR membran BC-AST juga menunjukkan nilai yang mendekati nilai LTUR yang direkomendasikan untuk pembalut luka yaitu $2000-2500 \mathrm{~g} / \mathrm{m}^{2} /$ hari. Hasil ini mengindikasikan bahwa BCAST3 dan BC-AST5 sangat berpotensi untuk digunakan sebagai pembalut luka yang bersifatantimikroba.

\section{UCAPAN TERIMA KASIH}

Penulis mengucapkan terima kasih kepada ibu Dewi Sekar Pangerteni atas diskusi dan bantuannya selama melakukan penelitian.

\section{DAFTAR PUSTAKA}

1. W.K. Czaja, D.J. Young, M. Kaweckj, R.M. Jr Brown.Reviews: Thefuture prospects of microbial cellulose in biomedical applications.

Biomacromolecules. 8: 1-12 (2007)

2. M. Iguchi, S. Yamanaka, A. Budhiono. Bacterial cellulose-a masterpiece of nature's arts. J. Mater. Sci. 35: 261-270 (2000)

3. M.Zaborowska, A. Bodin, $\mathrm{H}$. Bäckdahl, J. Popp, A. Goldstein, P. Gatenholm. Microporous bacterial
Cellulose as a potential scaffold for bone regeneration. Acta Biomater. 6: 2540-2547 (2010)

4. F. Lina, Z. Yue, J. Zhang, Y. Guang. Biomedical engineering-frontiers and challenges: Bacterial cellulose for skin repair materials. R. Fazel, editor.InTech Publisher, Croatia, 2011, pp 249-274.

5. B. Balakrishnan, M. Mohanty, P.R. Umashankar, A. Jayakrishnan. Evaluation of an in situforming hydrogel wound dressing based on oxidized alginate and gelatin. Biomaterials.26: 6335-6342 (2005).

6. X.Z. Shu, K.J. Zhu, W. Song. Novel $\mathrm{pH}$-sensitive citrate cross-linked chitosan film for drug controlled release. Int. J. Pharm. 212: 19-28 (2001)

7. W.C. Lin, C.C. Lien, H.J. Yeh, C.M. $\mathrm{Yu}, \mathrm{S}$. Hsu. Bacterial cellulosechitosan membranes for wound dressing applications, Carbohyd.Polym. 94: 603- 611 (2013)

8. A. Salam, J.J Pawlak, R.A. Venditti, K. El-tahlawy. Synthesis and characterization of starch citratechitosan foam with superior water and saline absorbance properties. Biomacromolecules. 11:1453-1459 (2010)

9. R.K. Pundir, P. Jain. Evaluation of five chemical food preservatives for their antibacterial activity against bacterial isolates from bakery products and mango pickles. J. Chem. Pharm. Res. 3:24-31 (2011)

10. B.S. Vukušić, F.S. Grgac, A. Budimir, S. Kalenić. Cotton textiles modified with citric acid as efficient antibacterial agent for prevention of 
nosocomial infections, Croat. Med. J. 52: 68-75 (2011)

11. D. Darwis. Effect of gamma irradiation on microbial cellulose membrane for application in guided bone regeneration (GBR). J. Ilmiah Aplikasi Isotop dan Radiasi.5: 83102 (2009)

12. D. Queen, J.D.S. Gaylor, J.H. Evans, J.M. Courtney. The preclinical evaluation of the water vapour transmission rate through burn wound dressings. Biomaterials. 8: 367-371. (1987)

13. M.T. Madigan, J.M. Martinko, J. Parker, J., Biology of microorganisms, $8^{\text {th }}$ ed. Prentice Hall International, NewJersey, 1997, pp 406-408.

14. Indriyati, R. Yudianti, M. Karina. Development of nanocomposites from bacterial cellulose and poly(vinyl alcohol) using casting-drying methods. Procedia Chemistry. 4: 7379 (2012) 